\title{
FORMATION OF DOUBLE DIVALENT METAL-AMMONIUM CONDENSED PHOSPHATES IN THE $\mathrm{NH}_{4} \mathrm{PO}_{3}$ MELT
}

\author{
ANATOLY SELEVICH, ELENA GRUSHEVICH, LUDMILA IVASHKEVICH, \\ GALINA KRUL, NATALIA ILUSHCHENKO, and ANATOLY LESNIKOVICH \\ Physico-Chemical Research Institute of Belarusian State University, \\ 14 Leningradskaya Str., Minsk, 220050, Belarus
}

\begin{abstract}
Thermal behavior of the $\mathrm{MO}-\mathrm{NH}_{4} \mathrm{PO}_{3}$ systems where $\mathrm{M}=\mathrm{Mg}, \mathrm{Ca}, \mathrm{Sr}$, $\mathrm{Ba}, \mathrm{Mn}, \mathrm{Co}, \mathrm{Ni}, \mathrm{Cu}, \mathrm{Zn}, \mathrm{Cd}$, and $\mathrm{Pb}$ was studied at 300 and $400{ }^{\circ} \mathrm{C}$. General regularities of formation of double divalent metal-ammonium phosphates were established. Conditions of preparation of some known and novel binary divalent metal-ammonium phosphates, $\mathrm{M}\left(\mathrm{NH}_{4}\right)_{2}\left(\mathrm{PO}_{3}\right)_{4}(\mathrm{M}=\mathrm{Mg}, \mathrm{Ca}, \mathrm{Mn}, \mathrm{Co}, \mathrm{Zn}$, and $\mathrm{Cd}), \mathrm{M}\left(\mathrm{NH}_{4}\right)_{2} \mathrm{P}_{4} \mathrm{O}_{12}(\mathrm{M}=\mathrm{Sr}$ and $\mathrm{Pb}), \mathrm{MNH}_{4}\left(\mathrm{PO}_{3}\right)_{3}(\mathrm{M}=\mathrm{Mg}, \mathrm{Co}, \mathrm{Ni}, \mathrm{Cu}, \mathrm{Zn}$, and $\mathrm{Pb}), \mathrm{MNH}_{4} \mathrm{P}_{3} \mathrm{O}_{9}(\mathrm{M}=\mathrm{Mg}, \mathrm{Ca}, \mathrm{Mn}$, and $\mathrm{Cd}), \mathrm{Ba}_{2} \mathrm{NH}_{4}\left(\mathrm{PO}_{3}\right)_{5}$, $\mathrm{Cu}_{3}\left(\mathrm{NH}_{4}\right)_{2} \mathrm{P}_{8} \mathrm{O}_{24}$, and $\mathrm{Ba}\left(\mathrm{MH}_{4}\right)_{4}\left(\mathrm{PO}_{3}\right)_{6}$ were determined. Preliminary XRD studies have been performed for powder samples of $\mathrm{Ba}_{2} \mathrm{NH}_{4}\left(\mathrm{PO}_{3}\right)_{5}$ (space group $P c$, unit cell dimensions $\left.a=8.649(1), b=7.312(1), c=13.873(2) \AA ; \beta=128.14(1)^{\circ}\right)$ and $\mathrm{Ba}\left(\mathrm{NH}_{4}\right)_{4}\left(\mathrm{PO}_{3}\right)_{6}$ (space group $P 31 c$, unit cell dimensions $a=11.1911(2), c=$ 8.9375(2) $\AA$ ).
\end{abstract}

\section{INTRODUCTION}

Double metal-ammonium condensed phosphates are of great practical interest because they reveal flame retardant properties in polyamides. ${ }^{1,2)}$ As a rule, the compounds are prepared by heating corresponding oxides or hydroxides with ammonium monophosphates. However, this technique has specific limitations. ${ }^{3)}$ Our recent investigations showed that ammonium polyphosphate $\mathrm{NH}_{4} \mathrm{PO}_{3}$ (APP) was convenient reagent for the preparation of double ammonium-containing condensed phosphates. ${ }^{4-8)}$ The use of APP allowed to synthesize several new double condensed phosphates which cannot be prepared by other techniques.

Conditions of the preparation of double tetravalent metal-ammonium tetraphosphates $\mathrm{M}\left(\mathrm{NH}_{4}\right)_{2} \mathrm{P}_{4} \mathrm{O}_{13}$ where $\mathrm{M}=\mathrm{Si}, \mathrm{Ge}, \mathrm{Sn}$, and Ti were elaborated earlier. ${ }^{6)}$ The aim of this study was to establish regularities of the formation of double divalent metal-ammonium condensed phosphates in the APP melt, to develop a convenient technique for synthesis of well-known and novel phosphates, and to characterize novel obtained compounds. 


\section{EXPERIMENTAL}

Reagent-grade $\mathrm{Mg}(\mathrm{OH})_{2}, \mathrm{CaCO}_{3}, \mathrm{Sr}\left(\mathrm{NO}_{3}\right)_{2}, \mathrm{BaO}, \mathrm{MnO}_{2}, \mathrm{Co}(\mathrm{OH})_{2}, \mathrm{Cu}(\mathrm{OH})_{2}$, $\mathrm{NiCO}_{3} \cdot 2 \mathrm{Ni}(\mathrm{OH})_{2} \cdot \mathrm{H}_{2} \mathrm{O}, \mathrm{CdCO}_{3}, \mathrm{~Pb}\left(\mathrm{NO}_{3}\right)_{2}, \mathrm{PbO}$, and $\mathrm{NH}_{4} \mathrm{PO}_{3}$ were used as starting materials. It was shown earlier ${ }^{7)}$ that the temperature range of $300-400{ }^{\circ} \mathrm{C}$ was optimal for obtaining double divalent metal-ammonium condensed phosphates. In the present work, reactions of the above compounds with APP were studied at the temperatures 300 and $400{ }^{\circ} \mathrm{C}$ at the molar ratios MO : APP $=1: 3,1: 5$, and 1:8. Prepared mixtures were held at the above temperatures in air. Progress of the reactions was monitored by periodic sampling using X-ray diffraction (XRD) and optical microscopy. Crystalline phases were separated from the mother fluxes by washing with water on a glass filter and dried at room temperature.

Synthesized compounds were identified by XRD, chemical analysis, and quantitative thin-layer chromatography (QTLC). X-ray powder diffraction data were obtained with HZG 4A powder diffractometer (Carl Zeiss, Jena). The $\mathrm{CuK}_{\alpha}$ radiation was selected by a Ni filter. The powder diffraction patterns were scanned in a step mode with a step width of $0.02^{\circ}(2 \theta)$. Indexing of the diffraction patterns was performed with the program TREOR $90 .{ }^{9}$ Standard procedures were used for chemical analysis of barium (gravimetry), phosphorus (photocolorimetry), and ammonia (the Keldal method). ${ }^{10)}$ The phosphate anions were identified by QTLC using the method proposed by Prodan et al. ${ }^{11)}$

\section{RESULTS AND DISCUSSION}

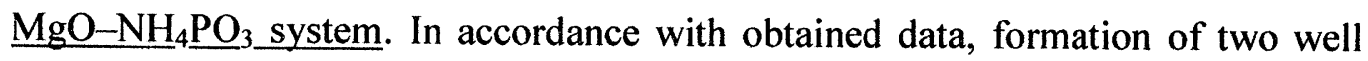
known, $\mathrm{MgNH}_{4}\left(\mathrm{PO}_{3}\right)_{3}$ and $\mathrm{MgNH}_{4} \mathrm{P}_{3} \mathrm{O}_{9}$, and a new $\mathrm{Mg}\left(\mathrm{NH}_{4}\right)_{2}\left(\mathrm{PO}_{3}\right)_{4}{ }^{7,8,12)}$ double magnesium-ammonium condensed phosphates was detected in the system. It was found that an increase of ammonium polyphosphate excess in mixtures expanded a crystallization temperature range of double magnesium-ammonium condensed phosphates in general case and double magnesium-ammonium polyphosphates in particular. An increase of temperature from 300 to $400{ }^{\circ} \mathrm{C}$ and of reaction time was found to cause the step-by-step crystallization of the following compounds:

$$
\mathrm{Mg}\left(\mathrm{NH}_{4}\right)_{2}\left(\mathrm{PO}_{3}\right)_{4} \rightarrow \mathrm{MgNH}_{4}\left(\mathrm{PO}_{3}\right)_{3} \text { or/and } \mathrm{MgNH}_{4} \mathrm{P}_{3} \mathrm{O}_{9} \rightarrow \mathrm{Mg}_{2} \mathrm{P}_{4} \mathrm{O}_{12} \text {. }
$$

It was found that $300{ }^{\circ} \mathrm{C}$ and the molar ratio $\mathrm{MgO}: \mathrm{APP}=1: 5$ were optimal for the $\mathrm{Mg}\left(\mathrm{NH}_{4}\right)_{2}\left(\mathrm{PO}_{3}\right)_{4}$ preparation. $\mathrm{MgNH}_{4} \mathrm{P}_{3} \mathrm{O}_{9}$ was obtained at the same ratio of reagents at $400{ }^{\circ} \mathrm{C}$. Polyphosphate $\mathrm{MgNH}_{4}\left(\mathrm{PO}_{3}\right)_{3}$ crystallizes in the system as admixture.

$\mathrm{CaO}-\mathrm{NH}_{4} \mathrm{PO}_{3}$ system. Tables 1 and 2 show kinetics of the formation of crystalline calcium phosphates in the $\mathrm{CaO}-\mathrm{APP}$ mixtures at 300 and $400{ }^{\circ} \mathrm{C}$. Known double cyclotriphosphate $\mathrm{CaNH}_{4} \mathrm{P}_{3} \mathrm{O}_{9}$ and a new polyphosphate $\mathrm{Ca}\left(\mathrm{NH}_{4}\right)_{2}\left(\mathrm{PO}_{3}\right)_{4}$ crystallize in the system. ${ }^{8,12)}$ 
TABLE 1 Crystalline products formed in the CaO-APP mixtures at $300^{\circ} \mathrm{C}$.

\begin{tabular}{cccc}
\hline Reaction & & $\mathrm{CaO}: \mathrm{APP}$ molar ratio \\
\cline { 2 - 4 } time, $\mathrm{h}$ & $1: 3$ & $1: 5$ & $1: 8$ \\
\hline 1 & $\mathrm{Ca}\left(\mathrm{NH}_{4}\right)_{2}\left(\mathrm{PO}_{3}\right)_{4}$ & $\mathrm{Ca}\left(\mathrm{NH}_{4}\right)_{2}\left(\mathrm{PO}_{3}\right)_{4}$ & $\mathrm{Ca}\left(\mathrm{NH}_{4}\right)_{2}\left(\mathrm{PO}_{3}\right)_{4}$ \\
& $\mathrm{CaNH}_{4} \mathrm{P}_{3} \mathrm{O}_{9}$ & & \\
2 & $\mathrm{Ca}\left(\mathrm{NH}_{4}\right)_{2}\left(\mathrm{PO}_{3}\right)_{4}$ & $\mathrm{Ca}\left(\mathrm{NH}_{4}\right)_{2}\left(\mathrm{PO}_{3}\right)_{4}$ & $\mathrm{Ca}\left(\mathrm{NH}_{4}\right)_{2}\left(\mathrm{PO}_{3}\right)_{4}$ \\
& $\mathrm{CaNH}_{4} \mathrm{P}_{3} \mathrm{O}_{9}$ & $\mathrm{CaNH}_{4} \mathrm{P}_{3} \mathrm{O}_{9}$ & \\
10 & $\mathrm{CaNH}_{4} \mathrm{P}_{3} \mathrm{O}_{9}$ & $\mathrm{CaNH} \mathrm{P}_{3} \mathrm{O}_{9}$ \\
50 & $\mathrm{Ca}\left(\mathrm{PO}_{3}\right)_{2}$ & $\mathrm{Ca}\left(\mathrm{PO}_{3}\right)_{2}$ & $\mathrm{Ca}\left(\mathrm{PO}_{3}\right)_{2}$ \\
\hline
\end{tabular}

TABLE 2 Crystalline products formed in the CaO-APP mixtures at $400^{\circ} \mathrm{C}$.

\begin{tabular}{cccc}
\hline $\begin{array}{c}\text { Reaction } \\
\text { time, } \mathrm{h}\end{array}$ & \multicolumn{3}{c}{$\mathrm{CaO}: \mathrm{APP}_{\text {molar ratio }}$} \\
\cline { 2 - 4 } 0.2 & $\mathrm{CaNH} \mathrm{P}_{3} \mathrm{O}_{9}$ & $1: 5$ & $1: 8$ \\
\hline & $\mathrm{Ca}\left(\mathrm{NH}_{4}\right)_{2}\left(\mathrm{PO}_{3}\right)_{4}$ & $\mathrm{Ca}\left(\mathrm{NH}_{4}\right)_{2}\left(\mathrm{PO}_{3}\right)_{4}$ \\
0.5 & $\mathrm{CaNH}_{4} \mathrm{P}_{3} \mathrm{O}_{9}$ & \\
& $\mathrm{CaNH}_{4} \mathrm{P}_{3} \mathrm{O}_{9}$ & $\mathrm{Ca}\left(\mathrm{NH}_{4}\right)_{2}\left(\mathrm{PO}_{3}\right)_{4}$ & $\mathrm{Ca}\left(\mathrm{NH}_{4}\right)_{2}\left(\mathrm{PO}_{3}\right)_{4}$ \\
1 & & $\mathrm{CaNH}_{4} \mathrm{P}_{3} \mathrm{O}_{9}$ & $\mathrm{CaNH}_{4} \mathrm{P}_{3} \mathrm{O}_{9}$ \\
15 & $\mathrm{CaNH}_{4} \mathrm{P}_{3} \mathrm{O}_{9}$ & $\mathrm{CaNH}_{4} \mathrm{P}_{3} \mathrm{O}_{9}$ & $\mathrm{CaNH}_{4} \mathrm{P}_{3} \mathrm{O}_{9}$ \\
\hline & $\mathrm{Ca}_{2} \mathrm{P}_{4} \mathrm{O}_{12}$ & $\mathrm{Ca}_{2} \mathrm{P}_{4} \mathrm{O}_{12}$ & $\mathrm{Ca}_{2} \mathrm{P}_{4} \mathrm{O}_{12}$ \\
\hline
\end{tabular}

As seen from Tables 1 and 2, the temperature $300^{\circ} \mathrm{C}$ and the molar ratio $\mathrm{CaO}$ : APP $=1: 5$ are optimal for the preparation of $\mathrm{Ca}\left(\mathrm{NH}_{4}\right)_{2}\left(\mathrm{PO}_{3}\right)_{4}$. For the synthesis of $\mathrm{CaNH}_{4} \mathrm{P}_{3} \mathrm{O}_{9}, 400^{\circ} \mathrm{C}$ and the same molar ratio of components should be recommended. An increase of temperature and reaction time gives rise to the consecutive crystallization of the following compounds:

$$
\mathrm{Ca}\left(\mathrm{NH}_{4}\right)_{2}\left(\mathrm{PO}_{3}\right)_{4} \rightarrow \mathrm{CaNH}_{4} \mathrm{P}_{3} \mathrm{O}_{9} \rightarrow \mathrm{Ca}\left(\mathrm{PO}_{3}\right)_{2} \text { or/and } \mathrm{Ca}_{2} \mathrm{P}_{4} \mathrm{O}_{12} \text {. }
$$

$\underline{\mathrm{SrO}-\mathrm{NH}_{4}} \underline{\mathrm{PO}}_{3} \underline{\text { system. }}$. Only one double condensed phosphate, well known strontium-diammonium cyclotetraphosphate $\mathrm{Sr}\left(\mathrm{NH}_{4}\right)_{2} \mathrm{P}_{4} \mathrm{O}_{12}$, ${ }^{12)}$ was found in the $\mathrm{SrO}-\mathrm{APP}$ system. The optimal conditions for the preparation of the compound are the temperature $300^{\circ} \mathrm{C}$ and the molar ratio $\mathrm{SrO}: \mathrm{APP}=1: 5$. An increase of temperature and reaction time results in the consecutive crystallization of $\operatorname{Sr}\left(\mathrm{NH}_{4}\right)_{2} \mathrm{P}_{4} \mathrm{O}_{12}$ and then $\operatorname{Sr}\left(\mathrm{PO}_{3}\right)_{2}$. In contrast to the two above systems, no double strontium-monoammonium condensed phosphates were detected.

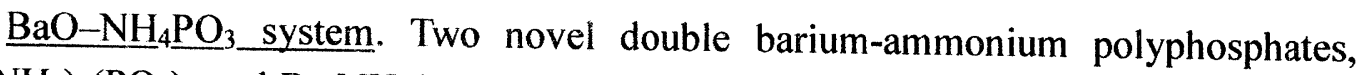
$\mathrm{Ba}\left(\mathrm{NH}_{4}\right)_{4}\left(\mathrm{PO}_{3}\right)_{6}$ and $\mathrm{Ba}_{2} \mathrm{NH}_{4}\left(\mathrm{PO}_{3}\right)_{5}$, were found in the $\mathrm{BaO}-\mathrm{APP}$ system. The mixture of these compounds were obtained earlier ${ }^{5)}$ and, unfortunately, incorrectly identified as $\mathrm{BaNH}_{4}\left(\mathrm{PO}_{3}\right)_{4}$. Table 3 shows indexed powder XRD data for $\mathrm{Ba}\left(\mathrm{NH}_{4}\right)_{4}\left(\mathrm{PO}_{3}\right)_{6}$. The compoud is isostructural with $\mathrm{BaCs}_{4}\left(\mathrm{PO}_{3}\right)_{6}{ }^{12)} 300{ }^{\circ} \mathrm{C}$ and the molar ratio $\mathrm{BaO}: \mathrm{APP}=$ $1: 8$ are acceptable for the preparation of $\mathrm{Ba}\left(\mathrm{NH}_{4}\right)_{4}\left(\mathrm{PO}_{3}\right)_{6}$. Indexed powder XRD data for $\mathrm{Ba}_{2} \mathrm{NH}_{4}\left(\mathrm{PO}_{3}\right)_{5}$ are presented in Table 4. The phosphate is isostructural with $\mathrm{Ba}_{2} \mathrm{~K}\left(\mathrm{PO}_{3}\right)_{5}$ and $\mathrm{Ba}_{2} \mathrm{Cs}\left(\mathrm{PO}_{3}\right)_{5}{ }^{1{ }^{12}}$ The optimal conditions for preparation of the compound are $300^{\circ} \mathrm{C}$ and the molar ratio $\mathrm{BaO}: \mathrm{APP}=1: 3$. An increase of temperature and 
reaction time causes the step-by-step crystallization of the following compounds in the system:

$$
\mathrm{Ba}\left(\mathrm{NH}_{4}\right)_{4}\left(\mathrm{PO}_{3}\right)_{6} \rightarrow \mathrm{Ba}_{2} \mathrm{NH}_{4}\left(\mathrm{PO}_{3}\right)_{5} \rightarrow \mathrm{Ba}\left(\mathrm{PO}_{3}\right)_{2}
$$

TABLE 3 Indexed powder XRD data $\left(\mathrm{CuK}_{\alpha}\right.$ radiation) for $\mathrm{Ba}\left(\mathrm{NH}_{4}\right)_{4}\left(\mathrm{PO}_{3}\right)_{6}$ (space group $P 31 c$, unit cell dimensions $a=11.1911(2), c=8.9375(2) \AA$ ).

\begin{tabular}{|c|c|c|c|c|c|c|c|c|c|}
\hline$h k l$ & $2 \theta_{\text {calc }}$, & $2 \theta_{\mathrm{obs}}, \mathrm{deg}$ & $\mathrm{d}_{\mathrm{obs}}, \AA$ & I, \% & $h k l$ & $2 \theta_{\text {calc, }}$ & $2 \theta_{\text {obs }}$, deg & $\mathrm{d}_{\mathrm{obs}}, \AA$ & $\mathrm{I}, \%$ \\
\hline 100 & 9.117 & 9.119 & 9.6903 & $\overline{45}$ & $\overline{302}$ & 34.22 & 34.224 & 2.6179 & 20 \\
\hline 10 & 13. & & 5707 & 39 & & & & 743 & 28 \\
\hline & & & & 100 & & & & & \\
\hline 002 & & & & & & & & & \\
\hline 28 & & & 99 & $<1$ & & & & & \\
\hline & & & & 59 & & & & & 12 \\
\hline & & & & 20 & & & & & \\
\hline & & & & 24 & & & & & 10 \\
\hline 2 & 27 & & & 3 & & & & & \\
\hline 3 & & & & 36 & & & & & 12 \\
\hline & & & & & & & & & 2 \\
\hline & & & & & & & & & 5 \\
\hline & & & & 13 & & & & & \\
\hline & & & 2.7974 & 19 & & & & & 2 \\
\hline 10 & 33.305 & 33.302 & 2.6883 & 4 & 313 & 45.408 & 45.405 & 1.9959 & \\
\hline
\end{tabular}

TABLE 4 Indexed powder XRD data $\left(\mathrm{CuK}_{\alpha}\right.$ radiation) for $\mathrm{Ba}_{2} \mathrm{NH}_{4}\left(\mathrm{PO}_{3}\right)_{5}$ (space group $P c$, cell dimensions $\left.a=8.649(1), b=7.312(1), c=13.873(2) \AA ; \beta=128.14(1)^{\circ}\right)$.

\begin{tabular}{|c|c|c|c|c|c|c|c|c|c|}
\hline$h k l$ & $2 \theta_{\text {calc }}, \mathrm{de}$ & $2 \theta_{\text {obs }}$, deg & $\mathrm{d}_{\mathrm{obs}}, \AA$ & $\mathrm{I}, \%$ & $h k l$ & $2 \theta_{\text {calc }}, \mathrm{d}$ & $2 \theta_{\mathrm{obs}}, \mathrm{deg}$ & $\mathrm{d}_{\mathrm{obs}}, \AA$ & I, \% \\
\hline 010 & 12.095 & 12.102 & 7.3073 & 20 & 013 & 27.368 & 27.367 & 3.2563 & 31 \\
\hline 100 & 13.005 & 13.010 & 6.7993 & 9 & & 27.680 & & 2196 & 5 \\
\hline & 13.099 & 13.093 & 6.7563 & 9 & & 28.931 & & 3.0831 & 39 \\
\hline 0 & 14. & 1 & 6. & 41 & 4 & & & 50 & 12 \\
\hline 1 & 15.859 & 15.854 & 5.5853 & 12 & $11-4$ & 29. & & 399 & 21 \\
\hline 00 & 16.235 & & 19 & 26 & & 31. & & 582 & 29 \\
\hline & & & & 12 & & & & & 20 \\
\hline 01 & 20. & & 4. & 10 & & & & & 32 \\
\hline 20 & 20.522 & 4 & 4. & 9 & & 34 & & 96 & 17 \\
\hline & 22.826 & & 3. & 27 & 4 & & & & 10 \\
\hline & 23.8 & & & 28 & & & & & \\
\hline 02 & 24.327 & & 3.6 & 3 & & & & 56 & \\
\hline 2 & 25.212 & 25. & 3.52 & 73 & 4 & & & 76 & 3 \\
\hline & 25.679 & & & 100 & & 37. & & 140 & 5 \\
\hline & 26.182 & & & 12 & & & & & 11 \\
\hline & 26.374 & & & 93 & & & & & 3 \\
\hline 10 & 26.496 & 26 & 3.3607 & 61 & 300 & 39.723 & 39.738 & 2.2664 & 2 \\
\hline $10-4$ & 26.639 & 26.638 & 37 & 27 & & & & & \\
\hline
\end{tabular}

$\underline{\mathrm{MnO}-\mathrm{NH}_{4}} \underline{\mathrm{PO}}_{3} \underline{\text { system. }}_{\text {It was shown earlier }}{ }^{13)}$ that $\mathrm{MnO}_{2}$ reacted with APP reducing $\mathrm{Mn}(\mathrm{IV})$ to $\mathrm{Mn}(\mathrm{II})$. Two double divalent manganese condensed phosphates, $\mathrm{Mn}\left(\mathrm{NH}_{4}\right)_{2}\left(\mathrm{PO}_{3}\right)_{4}$ and orthorhombic $\mathrm{MnNH}_{4} \mathrm{P}_{3} \mathrm{O}_{9}$, were found in the system. The optimal conditions for the formation of these compounds are the same as for isotypical 
calcium phosphates. An increase of temperature and reaction time results in the consecutive crystallization of the following compounds:

$$
\mathrm{Mn}\left(\mathrm{NH}_{4}\right)_{2}\left(\mathrm{PO}_{3}\right)_{4} \rightarrow \mathrm{MnNH}_{4} \mathrm{P}_{3} \mathrm{O}_{9} \rightarrow \mathrm{Mn}_{2} \mathrm{P}_{4} \mathrm{O}_{12}
$$

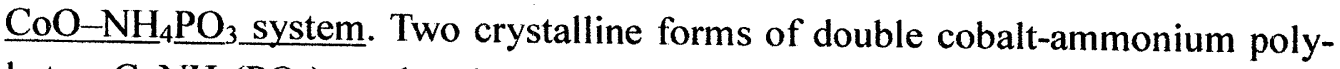
phosphate $\mathrm{CoNH}_{4}\left(\mathrm{PO}_{3}\right)_{3}$, rhombohedral $(r)$ and orthorhombic $(o)$, and cobalt-diammonium polyphosphate $\mathrm{Co}\left(\mathrm{NH}_{4}\right)_{2}\left(\mathrm{PO}_{3}\right)_{4}$ were found in the CoO-APP system. The consecutive crystallization of the following compounds was found by increasing the temperature and reaction time:

$$
\mathrm{Co}\left(\mathrm{NH}_{4}\right)_{2}\left(\mathrm{PO}_{3}\right)_{4} \rightarrow r-\mathrm{CoNH}{ }_{4}\left(\mathrm{PO}_{3}\right)_{3} \rightarrow o-\mathrm{CoNH}_{4}\left(\mathrm{PO}_{3}\right)_{3} \rightarrow \mathrm{Co}_{2} \mathrm{P}_{4} \mathrm{O}_{12} .
$$

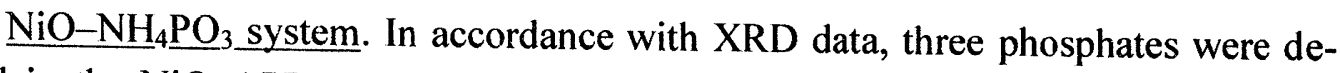
tected in the NiO-APP system. An increase of temperature and reaction time were found to cause the consecutive crystallization of the following compounds:

$$
\mathrm{X} \text {-phase } \rightarrow r-\mathrm{NiNH}_{4}\left(\mathrm{PO}_{3}\right)_{3} \rightarrow o-\mathrm{NiNH}_{4}\left(\mathrm{PO}_{3}\right)_{3} \rightarrow \mathrm{Ni}_{2} \mathrm{P}_{4} \mathrm{O}_{12} \text {. }
$$

Unfortunately, because of high solubility of X-phase, it was not isolated and identified. $\underline{\mathrm{CuO}-\mathrm{NH}_{4}} \mathrm{PO}_{3}$ system. An increase of temperature and reaction time were found to cause the consecutive crystallization of the compounds in the system CuO-APP:

$$
\mathrm{X} \text {-phase } \rightarrow \mathrm{CuNH}{ }_{4}\left(\mathrm{PO}_{3}\right)_{3} \rightarrow \mathrm{Cu}\left(\mathrm{PO}_{3}\right)_{2} \text {. }
$$

Cyclooctaphosphate $\mathrm{Cu}_{3}\left(\mathrm{NH}_{4}\right)_{2} \mathrm{P}_{8} \mathrm{O}_{24}$ was detected in the system as admixture at the temperature $300{ }^{\circ} \mathrm{C}$ and the molar ratio $\mathrm{CuO}: \mathrm{APP}=1: 3$.

$\underline{\mathrm{ZnO}-\mathrm{NH}_{4}} \mathrm{PO}_{3}$ system. Two double phosphates, well known $\mathrm{Zn}\left(\mathrm{NH}_{4}\right)_{2}\left(\mathrm{PO}_{3}\right)_{4}$ and orthorhombic $\mathrm{ZnNH}_{4}\left(\mathrm{PO}_{3}\right)_{3},{ }^{12)}$ were found in the system $\mathrm{ZnO}-\mathrm{APP} .300{ }^{\circ} \mathrm{C}$ and the molar ratio $\mathrm{ZnO}: \mathrm{APP}=1: 5$ are optimal for the $\mathrm{Zn}\left(\mathrm{NH}_{4}\right)_{2}\left(\mathrm{PO}_{3}\right)_{4}$ preparation. An increase of temperature and reaction time was found to give rise to the step-by-step crystallization of the following compounds:

$$
\mathrm{Zn}\left(\mathrm{NH}_{4}\right)_{2}\left(\mathrm{PO}_{3}\right)_{4} \rightarrow \mathrm{ZnNH}_{4}\left(\mathrm{PO}_{3}\right)_{3} \rightarrow \mathrm{Zn}_{2} \mathrm{P}_{4} \mathrm{O}_{12} \text {. }
$$

$\underline{\mathrm{CdO}-\mathrm{NH}_{4}} \mathrm{PO}_{3}$ system. Thermal behavior of the CdO-APP system is similar to that of $\mathrm{CaO}-\mathrm{APP}$. An increase of temperature and reaction time causes the consecutive crystallization of the compounds:

$$
\mathrm{Cd}\left(\mathrm{NH}_{4}\right)_{2}\left(\mathrm{PO}_{3}\right)_{4} \rightarrow \mathrm{CdNH}_{4} \mathrm{P}_{3} \mathrm{O}_{9} \rightarrow \mathrm{Cd}\left(\mathrm{PO}_{3}\right)_{2}
$$

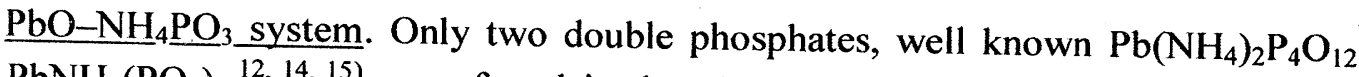
and $\mathrm{PbNH}_{4}\left(\mathrm{PO}_{3}\right)_{3},{ }^{12,14,15)}$ were found in the $\mathrm{PbO}-\mathrm{APP}$ system. An increase of tem- 
perature and reaction time causes the consecutive crystallization of the following compounds:

$$
\mathrm{Pb}\left(\mathrm{NH}_{4}\right)_{2}\left(\mathrm{PO}_{3}\right)_{4} \rightarrow \mathrm{PbNH}_{4}\left(\mathrm{PO}_{3}\right)_{3} \rightarrow \mathrm{Pb}\left(\mathrm{PO}_{3}\right)_{2}
$$

Conditions of the preparation of lead-ammonium phosphates were described earlier. ${ }^{15)}$

\section{$\underline{\text { SUMMARY }}$}

It was found that large majority of studied MO-APP systems $(\mathrm{M}=\mathrm{Mg}, \mathrm{Ca}, \mathrm{Mn}$, $\mathrm{Co}, \mathrm{Ni}, \mathrm{Cu}, \mathrm{Zn}, \mathrm{Cd}$, and $\mathrm{Pb}$ ) demonstrated similar schemes of transformations of crystalline phases. An increase of reaction time and temperature from 300 to $400{ }^{\circ} \mathrm{C}$ causes the step-by-step crystallization of the following compounds:

$$
\begin{aligned}
& \mathrm{M}\left(\mathrm{NH}_{4}\right)_{2}\left(\mathrm{PO}_{3}\right)_{4} \text { or } \mathrm{M}\left(\mathrm{NH}_{4}\right)_{2} \mathrm{P}_{4} \mathrm{O}_{12} \rightarrow \mathrm{MNH}_{4}\left(\mathrm{PO}_{3}\right)_{3} \text { or/and } \mathrm{MNH}_{4} \mathrm{P}_{3} \mathrm{O}_{9} \rightarrow \\
& \mathrm{M}\left(\mathrm{PO}_{3}\right)_{2} \text { or/and } \mathrm{M}_{2} \mathrm{P}_{4} \mathrm{O}_{12} \text {. }
\end{aligned}
$$

The obtained results show that the use of APP is a powerful technique for preparation of large number of known and novel condensed phosphates.

\section{REFERENCES}

1) G.F. Levchik, S.V. Levchik, A.F. Selevich, A.I. Lesnikovich A.I., A.V. Lutsko, and L. Costa, Fire Retardancy of Polymers. The Use of Intumescence, edited by M. Le Bras et al., Cambridge (UK): Royal Chem. Soc.. 280 (1998).

2) S. Duquesne, M. Le Bras, S. Bourbigot, and R. Delobel, Phos. Res. Bull., 10, 88 (1999).

3) Z.A. Konstant and A.P. Dindune, Divalen Metal Phosphates, Zinatne, Riga (1987) (In Russian).

4) A.F. Selevich, G.F. Levchik, and A.I. Lesnikovich and S.V. Levchik, Belarusian Patent 260A, (1994).

5) A.F. Selevich, S.V. Levchik, A.S. Lyakhov, G.F. Levchik, A.I Lesnikovich, and J.-M. Catala, J. Solid State Chem. 125,43 (1996).

6) A.F. Selevich, L.S. Ivashkevich, K.I. Khurs, A.S. Lyakhov, and A.I. Lesnikovich, Phos. Res. Bull., 13, 227 (2002).

7) E.V. Grushevich, A.F. Selevich, and A.I. Lesnikovich, Sviridov readings. Iss. 1. Minsk, 16 (2004) (in Russian).

8) A.F. Selevich, L.S. Ivashkevich, E.V. Grushevich, and A.I. Lesnikovich, Phos. Res. Bull., 18, 93 (2005).

9) P.E. Werner, L. Eriksson, and M. Westdahl, J. Appl. Crystallogr., 18, 367 (1985).

10) G. Charlot, Les Méthodes de la Chimie Analytique, Paris, 1956.

11) E.A. Prodan, I.L. Shashkova, and T.N. Galkova, Zh. Anal. Khim., 33, 2304 (1978).

12) A. Durif, Crystal chemistry of condensed phosphates, Plenum Press, New York, 1995.

13) G.F. Levchik, S.V. Levchik, P.D. Sachok, A.F. Selevich, A.S. Lyakhov, and A.I. Lesnikovich, Thermochim. Acta, 257, 117 (1995).

14) B.M. Gatehouse and L.W. Guddat, Acta Crystallogr., C43, 1659 (1987).

15) A.F. Selevich, A.S. Lyakhov, A.I. Lesnikovich, and L.S. Ivashkevich, Phos. Res. Bull., 12, 99 (2001). 